\title{
Public perceptions of a rip current hazard education program: "Break the Grip of the Rip!"
}

\author{
Chris Houser $^{1}$, Sarah Trimble ${ }^{2}$, Robert Brander ${ }^{3}$, B. Chris Brewster ${ }^{4}$, Greg Dusek ${ }^{5}$, Deborah Jones ${ }^{6}$, and John Kuhn ${ }^{5}$ \\ ${ }^{1}$ Department of Earth and Environmental Sciences, University of Windsor, 401 Sunset Avenue, \\ Windsor, N9B 3P4, Ontario, Canada \\ ${ }^{2}$ Department of Geography, Texas A\&M University, 810 O\&M Building, College Station, 77843-3148, Texas, USA \\ ${ }^{3}$ School of Biological, Earth and Environmental Sciences, UNSW Sydney, Sydney, NSW 2052, Australia \\ ${ }^{4}$ United States Lifesaving Association, Huntington Beach, CA 92648, USA \\ ${ }^{5}$ NOAA/National Ocean Service, Center for Operational Oceanographic Products and Services, \\ 1305 East West Highway, SSMC4 \#6636, Silver Spring, MD 20910, USA \\ ${ }^{6}$ National Weather Service, Marine, Tropical, and Tsunami Services Branch, Silver Spring, MD 20910, USA
}

Correspondence to: Chris Houser (chouser@uwindsor.ca)

Received: 9 January 2017 - Discussion started: 30 January 2017

Revised: 12 May 2017 - Accepted: 31 May 2017 - Published: 4 July 2017

\begin{abstract}
Rip currents pose a major global beach hazard; estimates of annual rip-current-related deaths in the United States alone range from 35 to 100 per year. Despite increased social research into beach-goer experience, little is known about levels of rip current knowledge within the general population. This study describes the results of an online survey to determine the extent of rip current knowledge across the United States, with the aim of improving and enhancing existing beach safety education material. Results suggest that the US-based "Break the Grip of the Rip!" ${ }^{\circledR}$ campaign has been successful in educating the public about rip current safety directly or indirectly, with the majority of respondents able to provide an accurate description of how to escape a rip current. However, the success of the campaign is limited by discrepancies between personal observations at the beach and rip forecasts that are broadcasted for a large area and time. It was the infrequent beach user that identified the largest discrepancies between the forecast and their observations. Since infrequent beach users also do not seek out lifeguards or take the same precautions as frequent beach users, it is argued that they are also at greatest risk of being caught in a dangerous situation. Results of this study suggest a need for the national campaign to provide greater focus on locally specific and verified rip forecasts and signage in coordination with lifeguards, but not at the expense of the successful national awareness program.
\end{abstract}

\section{Introduction}

Rip currents (often called "rips" or "rip tides") are strong, narrow seaward flows driven by alongshore variations in wave setup landward of the breaker zone. Due to their dependence on wave breaking, rips can develop in any beach environment in oceanic, sea, and lacustrine environments. Castelle et al. (2016b) classify rips as (1) boundary rips that develop along both natural and engineered structures including headlands, groins and piers; (2) bathymetric rips that develop in response to the variability of the nearshore morphology; and (3) hydrodynamic rips that are spatial and temporally variable and develop in the absence of morphological variations or a lateral boundary. The type of rip that develops on a beach depends on the local wave climate and geology. For example, rips in the Great Lakes tend to be associated with natural headlands or the presence of large groins or harbor jetties, while rips in Florida and Texas tend to be bathymetrically controlled and associated with a transverse bar and rip nearshore morphology (Houser et al., 2013). Rips also vary regionally based on the driving forces, with rips on the Great Lakes typically associated with moderate to strong winds, while on the West Coast of the United States the rips are often associated with large swell events independent of the wind. 
Rips are capable of carrying unsuspecting bathers significant distances away from the shoreline with speeds reaching over $2 \mathrm{~m} \mathrm{~s}^{-1}$. As a consequence, rips are considered a major public health problem in the USA, Australia, Costa Rica, and many other countries (Short and Hogan, 1994; Klein et al., 2003; Hartmann, 2006; Sherker et al., 2008; Sabet and Barani, 2011; Woodward et al., 2013; Arun Kumar and Prasad, 2014; Arozarena et al., 2015). In Australia, rip currents are believed to be responsible for approximately 13000 beach rescues per year (SLSA, 2016) and an average of 21 confirmed deaths per year (Brighton et al., 2013), which exceeds fatalities caused by most other natural hazards (Brander et al., 2013). While it has been estimated that 30-40 individuals drown each year in rip-current-related incidents in the United States (Gensini and Ashley, 2010), Lushine (1991) suggested that rips may account for up to 150 fatal drownings per year and the United States Lifesaving Association (USLA) estimates this number to be over 100 per year. USLA's National Lifesaving Statistics Report (2012) indicates that over $82 \%$ of surf beach rescues in the US are rip current related and they therefore surmise that $82 \%$ of all fatal drownings at beaches are associated with rip currents.

Beach users' vulnerability to drowning in a rip current depends on a combination of nearshore hydrodynamic and bathymetric conditions, personal and group behaviors, and the beach safety and rip current knowledge of the individual (e.g., Houser et al., 2011a, b, 2016; Brander et al., 2011; Caldwell et al., 2013). Morgan et al. (2009) identified that lacking rip current knowledge was associated with rip current drownings, as was gender, age, alcohol consumption, and overconfidence in swimming ability. Recent evidence suggests that while most beach users are aware of rip currents and the hazard they pose, they are not able to identify a rip current (Sherker et al., 2010; Caldwell et al., 2013; Brannstrom et al., 2014). More than $80 \%$ of beach users surveyed in Florida and Texas failed to identify rip currents in photographs, usually by incorrectly identifying areas of breaking waves as the most hazardous swimming conditions (Brannstrom et al., 2014). This is consistent with results of Sherker et al. (2010), who argued that most beach users are unable to identify a rip current and that "beachgoers clearly need to know what a rip looks like to actively avoid swimming in it" (p. 1787). Given sufficient information, it is possible for beach users to identify a rip current with confidence (Hatfield et al., 2012). However, the ability to identify a rip current or to recognize posted warnings about the rip current danger is not a guarantee that a beach user will be safe, particularly because many will still choose to swim in unsafe and unpatrolled sections of the beach, away from the presence of lifeguards, for social or behavioral reasons or because of a lack of awareness and/or complacency (Drozdzewski et al., 2012, 2015; Williamson et al., 2012; Houser et al., 2016). Recent evidence suggests that beach access management can inadvertently steer unsuspecting beach users towards rip-prone areas, increasing the chances of a drown- ing occurring on that beach (see Barrett and Houser, 2012; Houser et al., 2015; Trimble and Houser, 2017).

Informing the public about the rip current hazard has become a national priority in several countries including the United States (e.g., Ashley and Black, 2008; Brannstrom et al., 2014), Australia (e.g., Sherker et al., 2008; Brighton et al., 2013), United Kingdom (e.g., Woodward et al., 2013), and Costa Rica (Arozarena et al., 2015). The United States has arguably the longest running cooperative and coordinated public rip current education program operating across various organizational and political levels (Carey and Rogers, 2005). The Rip Current Task Force was convened in 2003 by the National Oceanic Atmospheric Administration (NOAA) and USLA to establish consistent rip current education efforts and improve sharing of rip current rescue data across the United States. Subsequently, with the assistance of the National Weather Service (NWS) and Sea Grant, a national "Break the Grip of the Rip!" ${ }^{\circledR}$ education campaign was initiated in 2004. The Break the Grip of the Rip! ${ }^{\circledR}$ campaign aimed to educate the public about the rip current hazard by providing information about what rip currents are, why they are dangerous, how to identify them, what to do if caught in one, and how to help someone else if they are caught in a rip current. Aspects of this information have been disseminated through various means such as the NWS Rip Current Safety web page (http://www.ripcurrents.noaa.gov/), brochures, beach signs, videos, newspaper articles, and public service announcements on television.

While this campaign was the first of its kind globally, it was also particularly challenging given that the United States has four very different coastlines (West Coast, East Coast, Gulf Coast, Great Lakes) that differ in terms of wave climate and beach systems, and a large inland non-coastal population who may only visit any of these coastlines infrequently. Results from Brannstrom et al. (2015) suggest that while most beach users in Texas were not familiar with the campaign itself, many were familiar with a key message of the campaign on "what to do" when caught in a rip current. This suggests that the campaign may have been successful in educating beach users and reducing the number of drownings, but this hypothesis has never been formally tested.

The core visual image used in many of these interventions was a simple diagrammatic illustration of an idealized rip current from an oblique aerial perspective (Fig. 1). In this image, the rip current is characterized by relatively calm white water surrounded by more intensive wave breaking adjacent to the rip and close to the shoreline. An image template was created that could be accessed online and in hard copy and duplicated freely to be posted along boardwalks, beach fronts, and public beach access points throughout the United States. The image has also been more recently adopted in other countries such as Thailand, Costa Rica, Mexico, South Korea, and Japan. While the NOAA-USLA sign was not intended to teach the general population to identify a rip, the prominent image of a rip current on the sign and attempts to 


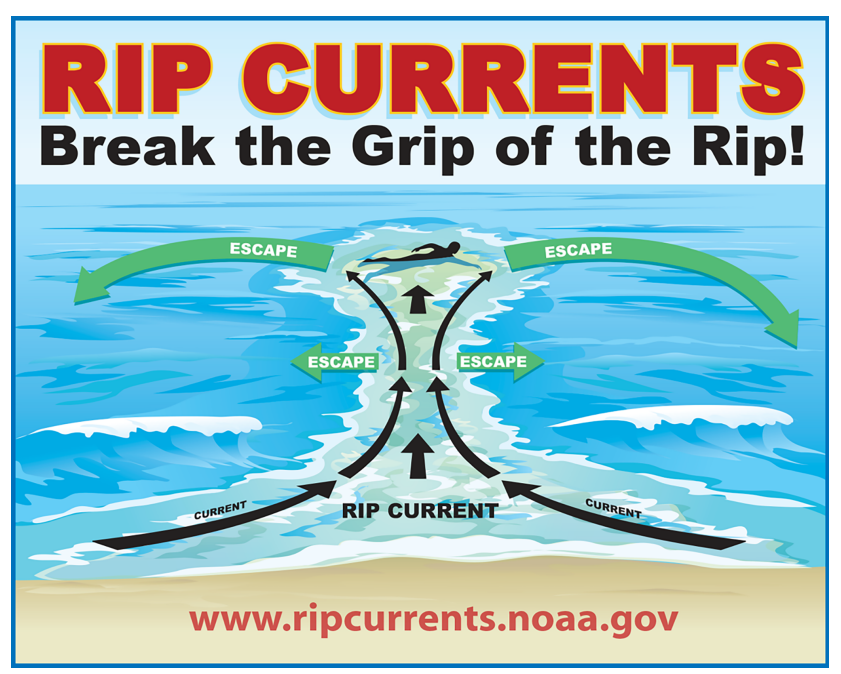

Figure 1. Rip current warning sign developed by the United States Rip Current Task Force as part of the "Break the Grip of the Rip!" ${ }^{\circledR}$ education campaign.

post the sign on beaches indicate that its function and visual argument constitute an invitation to beach users to use the information to identify rip currents (Brannstrom et al., 2015).

Due to this conflict between its' theoretical and practical use, the NOAA-USLA rip current sign has proven to be mostly successful in regard to educating beachgoers on "what to do" (e.g., swim parallel to the beach) when caught in a rip current, but it has not been particularly successful in improving beach users' ability to identify rip currents from the perspective of standing or sitting on the beach (Brannstrom et al., 2015). Consistent with results of Matthews et al. (2014), only a small percentage of beach users $(<50 \%)$ recalled observing rip current warning signs on beaches in Florida and Texas (Caldwell et al., 2012; Brannstrom et al., 2014) despite their widespread occurrence at beach access points. However, it is important to note that despite observing and understanding a warning sign, it is well established that some people will not take the appropriate actions to prepare for or avoid the hazard (Siegrist and Gutscher, 2006; Karanci et al., 2005; Hall and Slothower, 2009; Jóhannesdóttir and Gísladóttir, 2010).

In a separate initiative, the NWS has endeavored to develop a public rip current forecasting system, although the methodology varies among weather forecast offices (WFOs). Some WFOs issue surf zone forecasts that include a threetiered (low, moderate, high) rip current outlook communicated to the public during television and radio news broadcasts (Carey and Rogers, 2005) and social media platforms. Some WFOs work with local lifeguards to update their outlooks based on real-time observations. However, as discussed in NOAA (2015), these forecasts are not necessarily communicated or disseminated in a consistent manner throughout all regions and, therefore, are not communicated seam- lessly. The lack of consistency in forecasting is complicated by rip development being dependent on how the incident wave field interacts with the pre-existing nearshore morphology, which is difficult to predict without local knowledge on how it evolves over a range of spatial and temporal scales.

Since perception of the rip hazard depends in part on trust in experts and authorities, and trust in the protective measures they employ (Njome et al., 2010; Heitz et al., 2009; Terpstra, 2011; Terpstra et al., 2009; Barnes, 2002), inaccuracies in the forecast or a discrepancy between the forecast and what is observed at a specific beach at a specific time can erode confidence in the forecast (Siegrist and Cvetkovich, 2000; Espluga et al., 2009). Lack of confidence in forecasts could potentially condition beach users to downplay the hazard warning on future visits (Hall and Slothower, 2009; Scolobig et al., 2012; Green et al., 1991; Mileti and O'Brien, 1993). Furthermore, the generic nature of the rip current forecasts can result in situations where the actual intensity of rips varies substantially from the forecast. Beachgoers could easily observe a discrepancy between their beach location and the rip forecast, caused by either the generalized nature of the forecast or their inability to identify a rip current (Caldwell et al., 2012; Brannstrom et al., 2014, 2015).

The national US rip current education program is clearly an impressive effort yet many rip-current-related fatalities and rescues still occur on US beaches and overseas (Gensini and Ashley, 2010) and there is little quantitative evidence available to assess the overall effectiveness of the program. This is largely because no "pre-program" study was conducted on public understanding, perception, or behavior in relation to the rip current hazard. There is also a lack of hard data on rip-current-related fatalities, beach visitation numbers, and how incident frequency and exposure rate may have changed over time. In this regard, NOAA sponsored a workshop in 2015 to review the Break the Grip of the Rip! ${ }^{\circledR}$ program and NWS rip current forecasts to discuss whether existing messaging is scientifically sound, as well as effective and clear in reaching all age groups and demographics (NOAA, 2015)

It was acknowledged at the NOAA workshop that while there have been several recent studies to describe the extent of rip current knowledge amongst beach users (or lack thereof) on specific beaches in the United States (Caldwell et al., 2013; Brannstrom et al., 2014, 2015), there is insufficient understanding about beach user knowledge of rip currents and their behavior at the beach at a national level. This study describes results of a national online survey focused on US-based beachgoers and their understanding of, and experience with, the Break the Grip of the Rip! ${ }^{\circledR}$ program and the rip current hazard to provide quantitative evidence to guide future improvements to beach safety education material and forecasting efforts. 

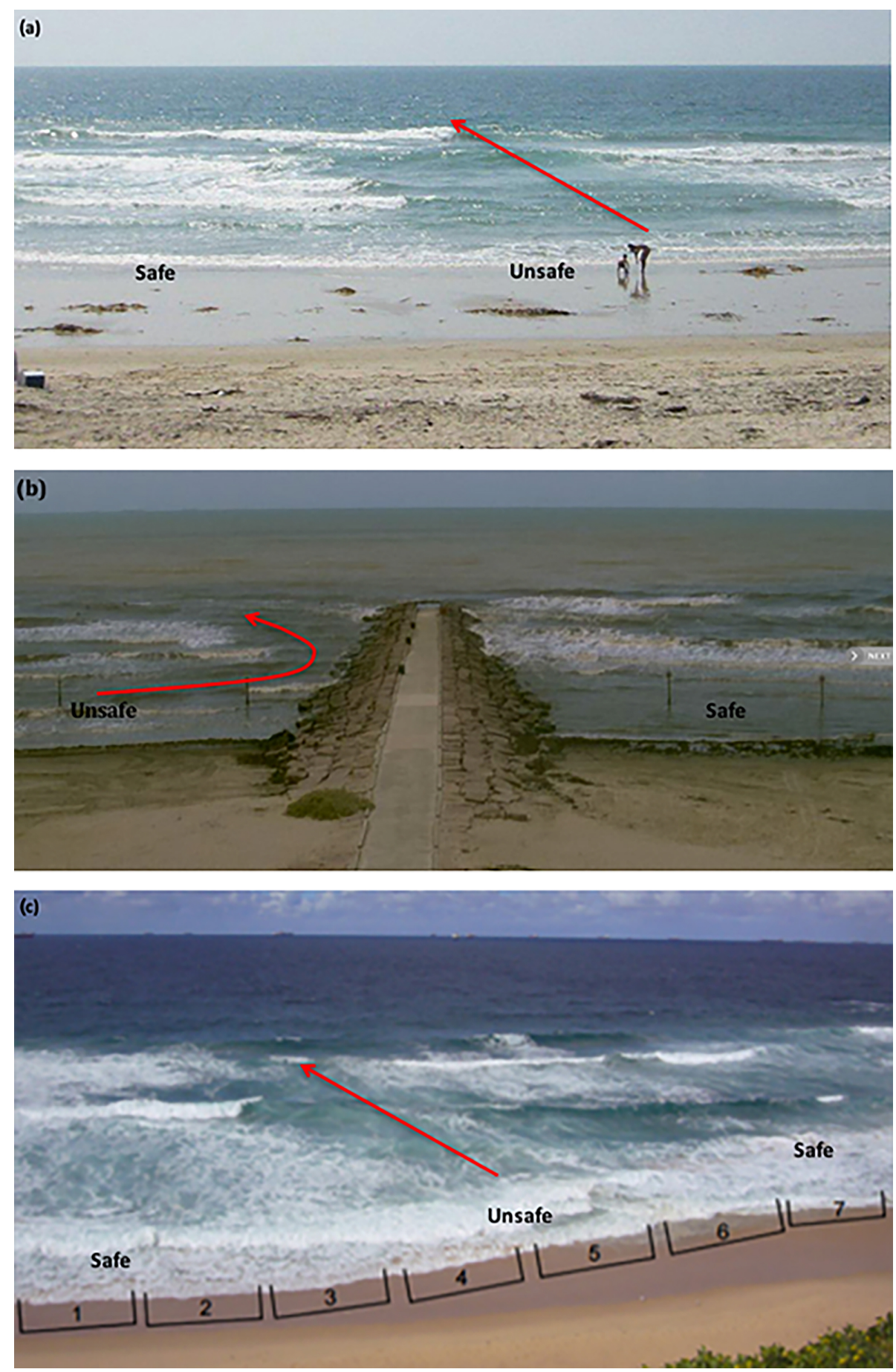

Figure 2. Photographs used in questions 42 through 44 of the survey to ask respondents, "Where on this photograph would you swim?" The location of the rip current in each photograph is shown by the red arrow, which was not visible to the respondents. 
Table 1. Question groups used to elicit responses from respondents notified about the survey by various agencies in the United States.

\begin{tabular}{lll}
\hline Group & Focus of questions & Example topics \\
\hline 1 & Informed consent & \\
2 & Non-identifying personal information & ZIP code, age, ethnicity, and beach use \\
3 & Swimming behavior & Self-assessed swimming ability \\
4 & Beach behavior and beach safety information & $\begin{array}{l}\text { Frequency of visits; perceived risks at the beach } \\
\text { Description of a rip current; ability to identify rip current }\end{array}$ \\
5 & Rip identification and knowledge & $\begin{array}{l}\text { in a photograph } \\
\text { Source of rip information; memory of observing rip safety warnings }\end{array}$ \\
6 & Memorability, conspicuity, comprehension, priming & $\begin{array}{l}\text { Sourning } \\
\text { warning }\end{array}$ \\
\hline
\end{tabular}

\section{Methodology}

The study research design relied on an Internet-based survey instrument using Qualtrics, approved by the relevant human subject protection program from Texas A\&M University. The survey consisted of questions re-phrased from Sherker et al. (2010) and photograph-based rip current identification protocols (Fig. 2) modified from Brannstrom et al. (2014, 2015), with questions grouped into six categories (Table 1). The survey had 75 questions and took approximately 20$30 \mathrm{~min}$ to complete. It remained open from May to August 2015 and all answers were recorded anonymously through Qualtrics Survey Software. A copy of the survey instrument is provided in the Appendix of this paper.

The survey was distributed by email to cooperating organizations and individuals for distribution though listservs, websites, social media, and in advertisements. It was disseminated via secure Internet and social media links for Texas A\&M University, Sea Grant, Science of the Surf, NWS, and the NOAA. While this Internet-based recruitment process attempted to target a much wider demographic of the US population, it is also reasonable to assume that as the host websites were all beach and surf-related, survey respondents likely had greater interest in, and understanding of, coastal environments and hazards, leading to a potential bias that was also experienced in a beach-safety-related study by Drozdzewski et al. (2012).

\section{Results}

Between May and August 2015, a total of 2084 respondents started the online survey, but only 1622 completed all questions (completion rate: $78 \%$ ). Geographically, the largest number of respondents were from the state of Texas $(n=368)$ where Texas Sea Grant and the local NWS office conducted significant advertisement for the survey. Large numbers of respondents also came from North Carolina $(n=214)$, California $(n=184)$, and Florida $(n=130)$, with most remaining states having $<50$ respondents. Of the 50 US states, only Nebraska did not have a respondent. Overall this cohort managed to capture respondents who use each of the coastlines in the continental US. Respondents were evenly distributed by age ( $>18$ years); each 10-year range between 21 and 60 garnered about between 320 and 420 respondents. A slight majority of the respondents were female $(55 \%)$.

\subsection{Familiarity with the Break the Grip of the Rip! ${ }^{\circledR}$ campaign}

Only $18 \%(n=304)$ of respondents reported hearing about the Break the Grip of the Rip! ${ }^{\circledR}$ campaign with nearly identical split by gender and age. Approximately $40 \%$ of respondents reported hearing about the campaign either through a brochure/pamphlet $(n=120)$ or at the entrance to a beach $(n=119)$, whereas 163 respondents $(54 \%)$ reported hearing about the campaign through various sources on the Internet. Ninety respondents reported having heard about the campaign from the Break the Grip of the Rip! ${ }^{\circledR}$ website. When asked what "break the grip of the rip" means, most respondents (familiar with the campaign) reported (to varying degrees of accuracy) that it was designed to provide information about what to do if caught in a rip current:

- "Do not try to fight the current, instead work with the current until you can break free of its pull."

- "Advises affected swimmers not to struggle while heading shoreward but to swim parallel to the beach till out of the off-beach current."

There were, however, several respondents (familiar with the campaign) who believed that the messaging was not appropriate and needed to be rethought:

- "The slogan is useless to anyone caught in a rip current! What can you do by knowing this slogan? ...'Wave, Yell \& Swim Parallel' is a far better slogan ... it provides three lifesaving pieces of information. The existing slogan provides nothing."

- "It's an advertising slogan; it doesn't mean much at all. It's a bad slogan; it does not tell folks what to do, what to watch for, or anything useful." 


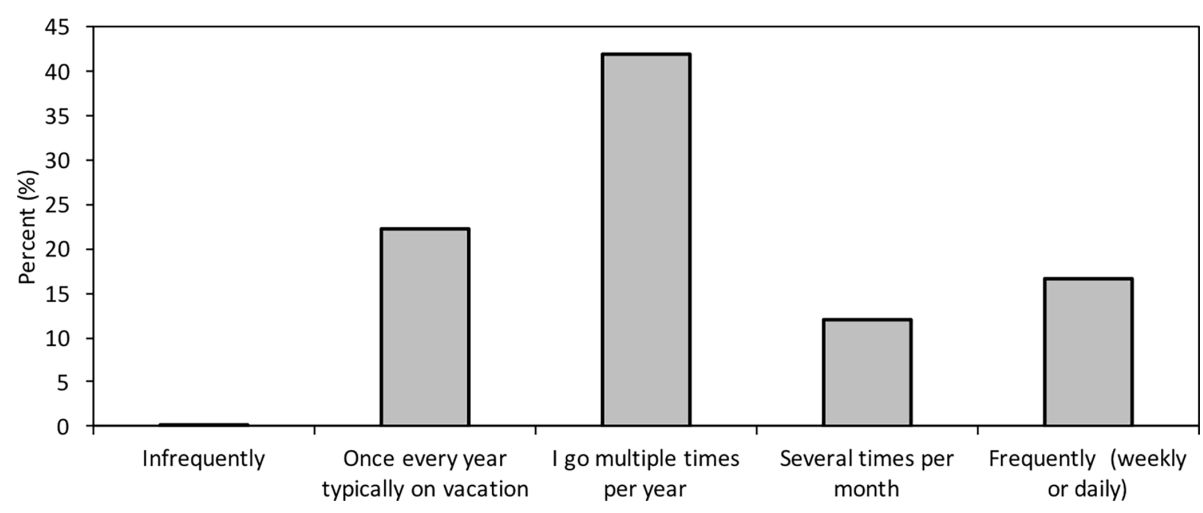

Figure 3. Percent of self-reported beach visitation by respondents.

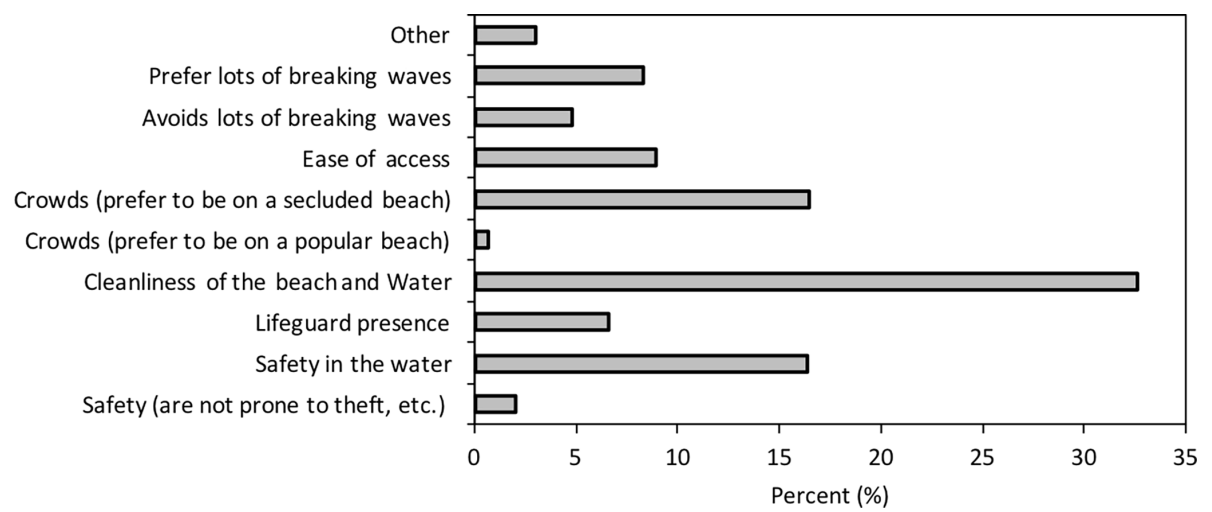

Figure 4. Relative importance of beach and surf factors to respondents when selecting a beach. Note that respondents were asked to identify all factors that applied.

Responses from those who were not familiar with the campaign were much shorter and did not contain the level about survival strategies provided by those familiar with the campaign. Representative responses include "how to escape", "tips to survive", and "how to get out of a rip".

\subsection{Beach preference}

As presented in Fig. 3, most respondents visited the beach either once per year on vacation (22\%) or multiple times per year $(42 \%)$. Visitation exhibits a statistically significant relationship with age, with older respondents $(>40)$ visiting the beach more often than younger respondents $\left(\chi^{2}=46.5\right.$, $\rho<0.01$ ). Perceived wave size on beaches visited by respondents depends on age and frequency of beach visitation with older respondents who visit the beach frequently tending to report beaches they visited having strong waves, while younger respondents, who tended to visit the beach infrequently, identified the beach as having small waves $\left(\chi^{2}=84\right.$, $\rho<0.01)$. In general, respondents who visit the beach infrequently tend to describe the beach as having small waves and that their primary beach activity is swimming and/or wading. All respondents who visit the beach frequently (weekly or daily) identified board riding as their main activity and tended to frequent beaches with strong wave activity $\left(\chi^{2}=\right.$ $111, \rho<0.01$ ), suggesting a greater understanding of wave conditions. There was no statistically significant variation in wave description based on home state, suggesting that perception of wave activity is largely based on frequency of beach visitation and other personal characteristics. In terms of choice of beach visited, wave activity and the potential hazard posed by rip currents or the absence of lifeguards are less important than cleanliness and at the same level of importance as crowds (Fig. 4).

When determining which beach to visit, frequent beach users, who were mostly board riders, tended to prefer beaches with lots of waves, whereas infrequent users emphasized safety and cleanliness $\left(\chi^{2}=159, \rho<0.01\right)$. Frequent beach users also believed it was very important to swim near a lifeguard, while infrequent users did not $\left(\chi^{2}=51\right.$, $\rho<0.01$ ). Across both groups, however, respondents suggested they would still enter the water even if a lifeguard was not present, suggesting that recognition about the importance of lifeguards is not consistent with behavior in selecting where and when to swim (Fig. 5). Frequent beach visitors were also more confident in their ability to "always" spot a rip current in contrast to infrequent beach visitors $\left(\chi^{2}=247\right.$, 


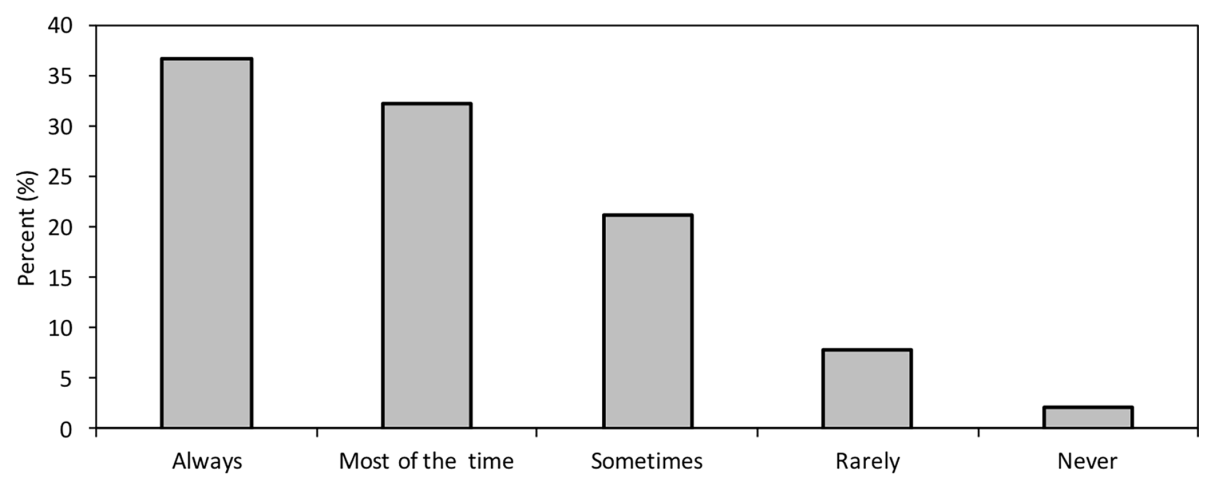

Figure 5. Self-reported tendency to enter the water in the absence of a lifeguard on a beach.

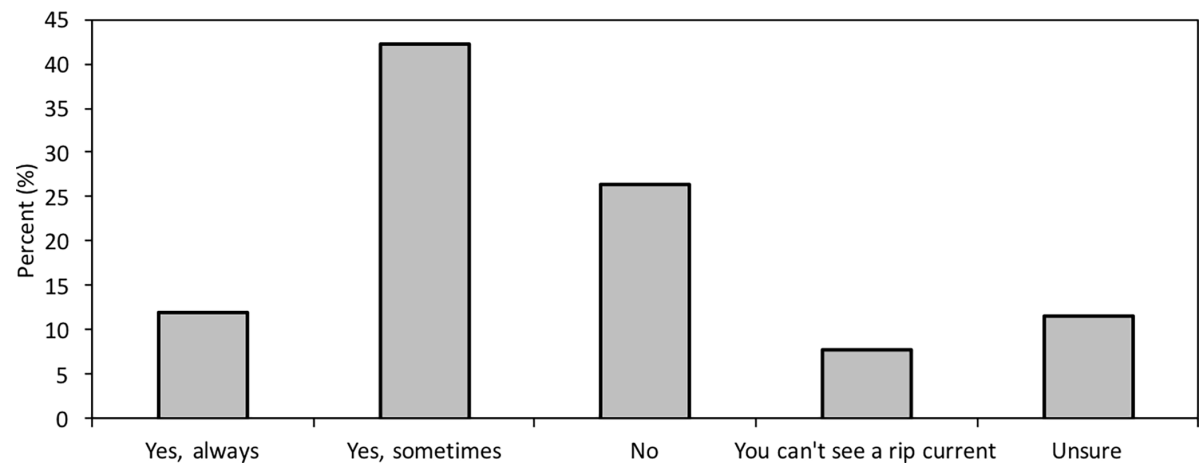

Figure 6. Percent of respondents' belief that rip currents can be seen by beach users.

$\rho<0.01$ ). Those who visit the beach less often (e.g., several times per year or month) believed they could spot a rip "sometimes" or believed it is not possible to see a rip current, consistent with the response from all respondents (Fig. 6).

\subsection{Swimming ability}

Most respondents $(\sim 52 \%)$ self-identified as competent swimmers (Fig. 7) and reported in a separate question that they were capable of swimming between 25 and 100 yards (22.8 and $91.4 \mathrm{~m})$ or more than 100 yards $(91.4 \mathrm{~m})$ without having to stop or pause in open water $\left(\chi^{2}=1391\right.$, $\rho<0.01)$. Respondents who self-reported as highly competent open water swimmers $(n=213,12 \%)$ primarily believed they could swim more than 500 yards in open water without resting, while those who self-reported as weak swimmers $(n=566,31 \%)$ believed that they were only capable of swimming 25 yards or less. Those who identified as highly competent or weak swimmers tended to have the narrowest range of self-reported ranges of swimming ability, while those who self-identified as competent swimmers had the widest range of self-reported swimming distances for both pools and open water.

\subsection{Ability to identify a rip current}

When asked "Where on this photograph would you swim?", approximately $54 \%$ of respondents correctly identified the location furthest away from the rip current in Photograph 1 (Figs. 2a and 8a). However, $182(11 \%)$ respondents incorrectly selected the rip current as the safest location to enter the water, with the remaining respondents identifying other areas of the photograph (adjacent to the rip) as being the safest location. Results of a $z$ test suggest that respondents who selected the rip as the safest location are significantly younger than those who correctly identified the safest location in the photograph $(z=12.1, \rho<0.01)$. Those who correctly identified the safest location in the photograph also visited beaches more frequently $(z=6.1, \rho<0.01)$ and self-reported beaches they visited as having strong waves $(z=6.4, \rho<0.01)$. Most respondents who identified the rip as the safest location self-reported never having swimming lessons $(z=2.8, \rho<0.01)$ and described themselves as weak swimmers in both pools $(z=3.7, \rho<0.01)$ and open water $(z=6.2, \rho<0.01)$. Those same respondents also self-reported that it was important to swim near a lifeguard $(z=5.8, \rho<0.01)$ but tended to not consider hazards before going to the beach, unlike respondents who were able to correctly identify the safest spot to enter the water $(z=14.1$, $\rho<0.01)$. 


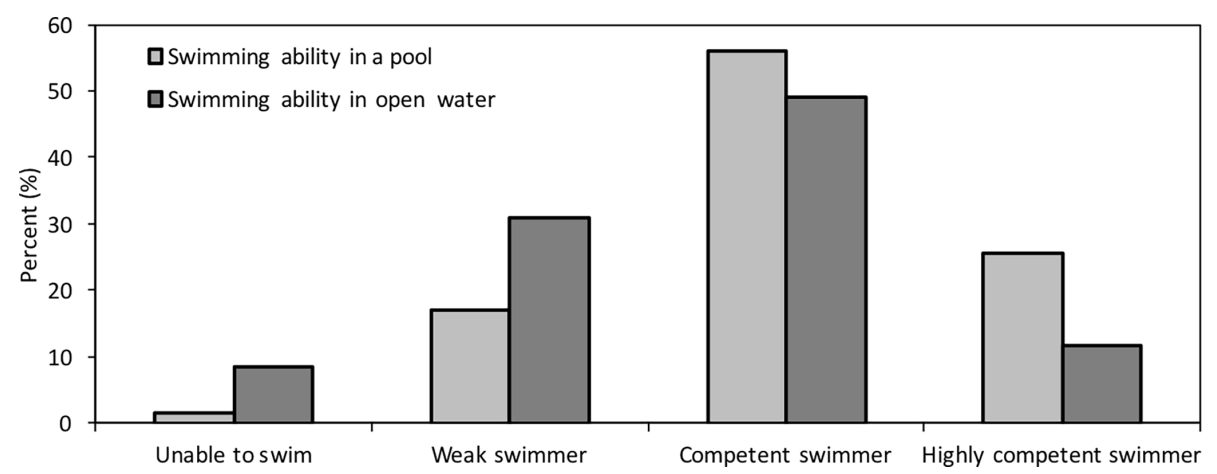

Figure 7. Percent of self-reported swimming ability in a pool and in open water with waves.

When asked what beach features they believed to be most dangerous, respondents who correctly identified the safest swimming location away from the rip were more likely to report alongshore currents and rip currents as dangerous features, while those who selected the rip as the safest location tended to identify jellyfish, sharks, and big waves. Respondents who incorrectly selected the rip current as the safest location were also least familiar with the common US beach safety flag system $(z=11.5, \rho<0.01)$ and tended to have not heard of rip currents $(z=17.3, \rho<0.01)$. Respondents who selected the rip as the safest location did not understand what was meant by a "high risk" $(z=3.2, \rho<0.01)$ or a "low risk" $(z=7.5, \rho<0.01)$ of rip current development as broadcast by some NWS services. The same respondents also noted that rip forecasts are apt to be inconsistent with the conditions they encountered on the beach, in contrast to respondents who correctly identified the safest location in the photograph and noted that forecasts tended to be consistent with their experience $(z=3.3, \rho<0.01)$.

Approximately $25 \%$ of respondents $(n=630)$ incorrectly identified the left side of the groin (with an active rip) as the safest spot to enter the water in Photograph 2 (Figs. 2b and $8 b$ ). Like the responses to Photograph 1, those respondents tended to be younger $(z=5.2, \rho<0.01)$, go to the beach infrequently $(z=7.8, \rho<0.01)$, and self-report waves being relatively small $(z=7.3, \rho<0.01)$ and their swimming ability in open water to be relatively poor $(z=2.2$, $\rho<0.01)$. These respondents are also unlikely to consider hazards before going to the beach $(z=10.9, \rho<0.01)$, are unfamiliar with the common beach flag system in the United States $(z=12.5, \rho<0.01)$, do not understand the definition of a "high-risk" of rip current development $(z=4.2$, $\rho<0.01$ ), and believe that rip forecasts are not consistent with their personal beach experiences $(z=2.8, \rho<0.01)$. Unlike responses for Photograph 1, those respondents who incorrectly identified the rip as the safest location were not significantly different (at the $95 \%$ confidence level) from those who correctly identified the safest location (right side of the groin) with respect to pool swimming, swimming near a lifeguard, type of water activity at the beach, knowledge of
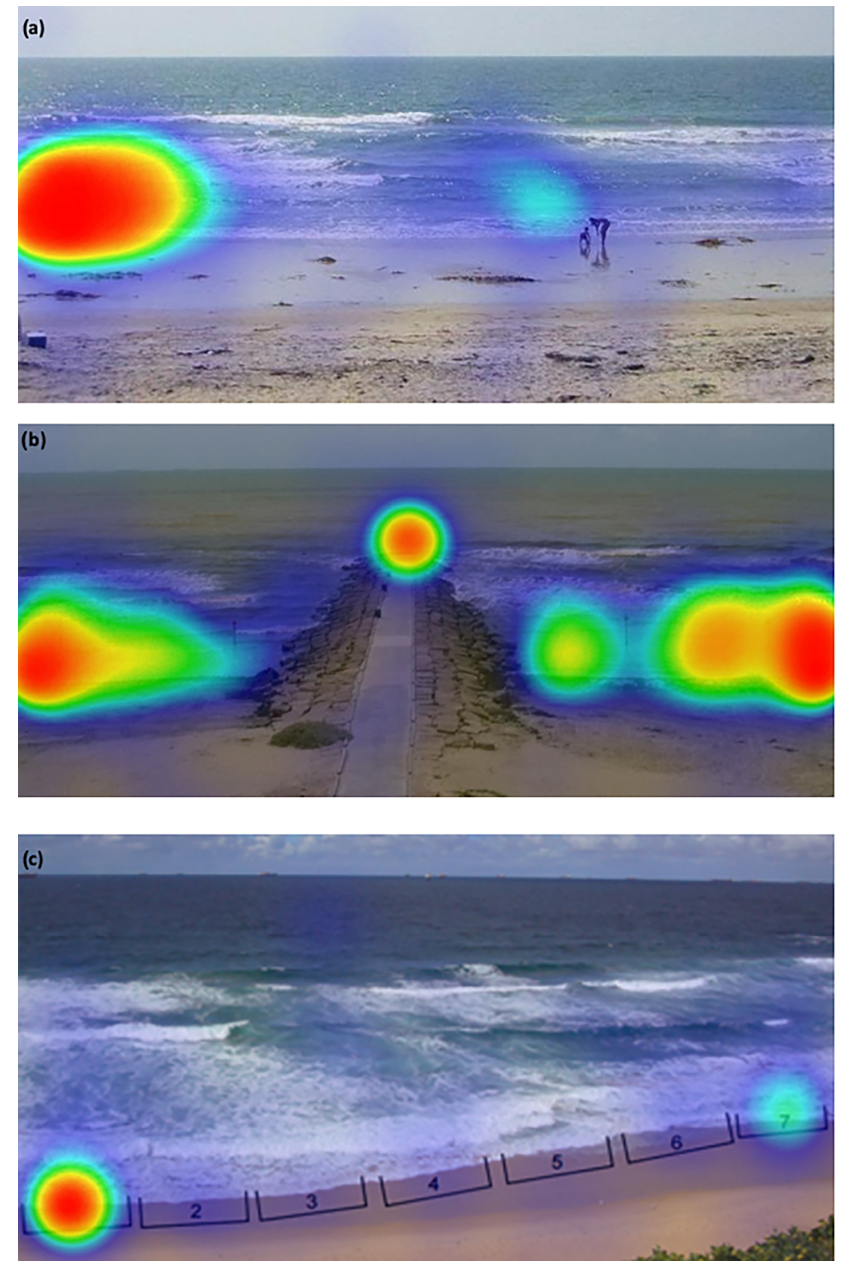

Figure 8. Identified location of safest location to enter the water in the photographs presented in questions 42 through 44 and also presented in Fig. 2. Warm (red) colors indicate large number of responses, while cold (blue) colors indicate few responses. No color (background picture) represents areas that received no responses.

the Break the Grip of the Rip! ${ }^{\circledR}$ campaign, or their perceived ability to use the sign to identify a rip current. 
A similar pattern was observed in respondents' ability to identify the safest location to enter the water in Photograph 3 (Figs. 2c and 8c), with $26 \%$ of respondents incorrectly identifying the rip current as the safest location. Like responses for the other photographs, respondents who identified the rip as the safest location to enter the water did not visit beaches as often $(z=4.5, \rho<0.01)$, self-reported having relatively limited swimming ability in pools $(z=3.1, \rho<0.01)$ and open water $(z=2.8, \rho<0.01)$, and did not believe it was important to swim near a lifeguard $(z=3.0, \rho<0.01)$, unlike those who correctly identified the safest location to enter the water in the photograph. Respondents who selected the rip current as safe for swimming were not as familiar with the flag system used in the United States $(z=5.6, \rho<0.01)$, rip currents $(z=3.9, \rho<0.01)$, or the Break the Grip of the Rip! ${ }^{\circledR}$ campaign $(z=4.4, \rho<0.01)$. These respondents also did not understand what was meant by a "low risk" $(z=2.5$, $\rho<0.01)$ and a "high risk" $(z=3.4, \rho<0.01)$ of rips. However, unlike photographs 1 and 2 , no statistically significant difference was observed between those who correctly or incorrectly identified the safest spot to enter the water with respect to age, self-reported wave activity, swimming lessons, behavior in the absence of lifeguards, importance of checking for hazards, or the ability to use the sign to identify a rip current.

\subsection{Response to the rip current warning sign}

Only $31 \%$ of all respondents believed the NOAA rip current warning sign could be used to identify a rip current. Interestingly, those respondents who incorrectly identified the rip current as the safest spot on the beach to enter the water tended to believe that the NOAA rip current warning sign could not help a beach user identify a rip current. This contrasted with those who correctly identified the safest location in any of the photographs $(z=5.2, \rho<0.01)$. When asked to describe how the sign could be used to identify a rip current, some of the latter respondents were able to relate the rip in the picture to a real rip:

- "It shows that in a rip current, there appears to be a break in the water, with water moving in a different direction."

- "It shows you the 'calm' area between the two areas of normal wave activity indicating the channel where the rip is located."

Most of these responses focused on the pattern of wave breaking and the orientation of the "calmer" water to the beach. There is evidence that some respondents believed the picture to be an accurate representation of a rip, but they could not provide specific detail about the real-world features on the beach it depicted, for example "graphic depiction of what the tide looks like". This suggests that some respondents believe the sign is accurate since it was designed and placed there by an authority.
As previously noted, the rip current warning sign was not designed to help beach users identify a rip current but rather to inform them how to escape a rip. Most respondents could clearly state what the sign was informing them about swimming parallel to the beach to escape a rip:

- "Let the current take you out and then swim parallel the shore to escape."

- "Swim parallel to the shore, or wait until the rip gets less strong further offshore."

Of the respondents, $96 \%$ could provide a response to this question and virtually all responses indicated that the sign informed them to swim parallel to shore to escape the rip current, suggesting that the sign has been effective in communicating this message. When asked how seeing this sign would change their behavior of the beach, a majority $(65 \%)$ of respondents suggested they would take precaution when entering the water:

- "Might avoid going in water if I see surface signs of rip activity and drive to another beach."

- "Consider not going in. Look carefully for signs of rips. Look for flags and lifeguards."

This suggests that while most respondents understood that the sign provided them with information on how to escape a rip current, it also helped with prevention as most respondents also noted that they would take precaution or use it to spot (and presumably avoid) a rip rather than focus on escape strategies.

Most respondents (86\%) provided ideas on how to improve the rip current warning sign, with more than half suggesting the sign needed to provide a more accurate depiction and/or description of a rip current:

- "I don't think it clearly identifies it enough that the waves will not break where a rip current is. It is great because it shows how to get out of one but I think with another picture of an actual rip current people would identify them easier."

- "Pictures showing what actual rip currents look like would be useful./Most casual beachgoers are not confident that they could identify a rip current from shore or predict where one might be forming."

- "There needs to be more info on how to detect, recognize and avoid a rip current. Information on conditions during which rip currents are most likely to form would also be useful."

A small number of respondents $(<10 \%)$ suggested that the sign should either include step-by-step instructions on what to do and/or provide more information about the experience of being caught in a rip current: 
- "Multiple steps: (1) know when you're in a rip; (2) stay calm and tread water; (3) wait until you've floated out to a slower moving water; (4) swim sideways."

- "Specific instructions on what one should do if caught in a rip current - Should I swim left, right, straight? What if I'm not a strong swimmer? What are some other exit options?"

Another group of respondents $(\sim 15 \%)$ either did not provide suggestions on how the sign can be improved or noted that it only needed minor edits, including space for local emergency numbers and contacts. A small number of respondents $(<5 \%)$ believed that the sign should include statements that elicit fear amongst beach users including statements such as "Rip currents can drown you".

\subsection{Prevention}

One in four $(25 \%)$ respondents reported they had been previously caught in a rip current by accident, while $10 \%$ of respondents reported that they had purposely entered a rip for surfing. When asked how to escape a rip, those who had accidently been caught in a rip current provided relatively detailed responses that either described escape by swimming parallel or riding the current without panic:

- "Let it flow. Don't fight it. Perhaps as long as you minimize tiring exertions try to flow towards the side of the current. Basically do the same thing you'd do if you fell in a strong river about to empty into a lake. You certainly wouldn't kill yourself trying to swim out upstream."

- "Don't panic!!! Either swim - without too much exertion - parallel to the beach for 25+ yards, OR tread water and allow yourself to be carried out until the rip loses power, then swim parallel to the beach. Once out of the rip, swim back towards shore (again in a relaxed manner, taking time to prevent exhaustion). When nearing the beach, take care not to get drawn back into the rip by water flow parallel to the shoreline."

Of those who had not been previously been in a rip $7 \%$ $(n=36)$ did not provide a description of how to escape. The remaining respondents provided relatively short responses that described escape through combinations of swimming parallel and relaxation

Assuming no response is an indication of a lack of knowledge about rips, the number of respondents who did not provide an accurate description of how to escape a rip current is $\sim 9 \%$, suggesting that overall the campaign has been successful in informing beach users to (1) not fight the current; (2) swim out of the current, then to shore; (3) if you can't escape, float or tread water; and (4) if you need help, call or wave for assistance.

\subsection{Forecasts}

Respondents were also asked about whether they were aware of rip forecasts, if forecasts altered their behavior, and if the forecasts conformed with their observations at the beach. Since existing rip forecasts are not consistent and few are based on an understanding of pre-existing morphology, the focus here was not on the actual accuracy of the forecast but on whether the respondent believed the message to be consistent with their observations. About half of respondents (52\%) reported seeking information about beach and surf conditions before going to a beach with the majority (83\%) using the Internet to find that information. A large majority $(88 \%)$ of respondents stated that information about beach and surf conditions affected their behavior, with many saying that they would either "not go" (to the beach), "not go in the water", or "look for rips". When asked whether the rip current forecast (either high or low) was consistent with conditions they experienced at the beach, approximately $67 \%$ of respondents stated that the forecasts were not necessarily consistent with their observations. For some, this inconsistency reflected the temporal and spatial broadness of the rip forecast compared to what they observed:

- "Weather changed quickly and no beach flags were posted, advising of rip currents."

- "Rip currents cannot be predicted for individual beaches, they are blanket warnings."

Other respondents noted the forecast was inaccurate because other beach users had not adjusted their behavior:

- "I never noticed an[y] thing unusual and people in general don't seem to adjust their behavior."

Others noted it was not possible to determine whether the forecast was accurate because they were not able to spot a rip on the beach at that specific time or in general:

- "I couldn't determine if/where rip tide activity might be in the water if the forecasts had warned beach-goers to be aware of a high risk on that day."

In several cases $(n=59)$, respondents noted they had not heard a forecast warning of the rip hazard on a given day or in general through responses such as "I don't know if I've ever heard a rip current forecast?"

Additional questions about high-risk rip conditions solicited written responses that suggest many respondents understood the high-risk warning to mean that wind and wave activity are tantamount to the development of rips:

- "Due to tides, weather, etc., there is a much greater risk for rip currents in the ocean."

There was a mix of responses in which respondents believed that "high risk" meant that rips would form or that 
there was a greater chance of rip formation. Others $(n=102)$ believed that the use of the terms high and low risk were misleading:

- "Whenever or wherever there are waves there can be rip currents, so I am not sure what "high" or "low" risk of rip currents means. All rips are potentially dangerous."

In response to the definition of low risk, respondents tended to suggest this implied that rips were unlikely or would not form:

- "Rip currents may still exist but are weaker or fewer than normal."

- "Conditions are not conducive to rip currents."

- "The factors necessary for rip currents to form are absent - not likely to encounter rip."

Of note, whether a respondent described high and low risk of rips as a probability (likely, unlikely) or in absolute terms (is or is not present) is not related to whether the respondent noted that the rip forecast was consistent with their observations at the beach. For both high and low risk, some respondents believed that the forecast (by radio, Internet, etc.) was not based on the predicted weather but rather on whether a rip had been sited on a beach or not with statements such as "not sighted" or "strong rips observed". Others $(n=129)$ believed that high and low risk was associated with the local bathymetry being conducive to the formation of rips: "the topography/bathymetry is suited to rip currents".

\subsection{Trusted sources of information}

Respondents were also asked to rank sources of information about rip currents from (1) most trusted to (5) least trusted. Except for social media (Facebook, Twitter, etc.), all sources of information were nearly equally ranked from most to least trusted with no discernable pattern. Only social media exhibited a discernable pattern, with more than $35 \%$ of respondents identifying it as the least trusted source, although $18 \%$ of respondents also identified it as the most trusted. More respondents identified Internet sources as the most trusted compared to other sources, while television and radio were identified as trusted (rank 2 and 3), but not the most trusted. No significant correlations were observed between trust in a source of information and respondent demographics, suggesting that a broad communication strategy is the most effective to reach the widest audience.

\section{Discussion}

The primary results of this US-based rip current survey are summarized in Table 2. Results suggest that while many are not aware of the Break the Grip of the Rip! ${ }^{\circledR}$ campaign, the US beach-going public is informed about rip current safety.
While this is an encouraging result, it needs to be placed in context. The goal of this study was to examine US-based beachgoers' understanding of, and experience with, the national Break the Grip of the Rip! ${ }^{\circledR}$ program and the rip current hazard to provide quantitative evidence for improving the program. Despite the dissemination of the online survey leading to a potentially biased cohort (Sect. 2) that was dominated by respondents who were relatively frequent beachgoers, self-rated as competent swimmers, and could successfully identify the safest location to enter the water based on photographs, approximately $10 \%$ of survey respondents were infrequent beachgoers, poor swimmers, largely ignorant of the rip current hazard, and more liable to make poor swim location choices.

When taking the entire US beach-going population into account, this cohort represents a significant population of potential "at-risk" beachgoers. Given that this population was a key target of the Break the Grip of the Rip! ${ }^{\circledR}$ campaign, it is therefore of considerable concern that this cohort (i) tended to select the rip current as the safest location to enter the water on each of the survey photographs, (ii) did not consider hazards before going to the beach, (iii) were not familiar with the beach flag system in the United States, and (iv) did not seek out lifeguards when visiting a beach. These results clearly highlight how at risk infrequent beach users still are despite the decadal existence and ongoing presence of the campaign.

In contrast, survey respondents who were frequent beachgoers and had previous experience with rip currents had a better understanding of what rip currents were, the danger they represent, and how to escape from a rip. As described by Brannstrom and Houser (2015), those who get caught in a rip current "understand the dangers of rips first hand and ... realize [they] never want to be caught in that situation or accident [again]." Similar results were found in studies involving surveys of people who had been caught in rip currents in Australia (Drozdzewski et al., 2012, 2015). Those with indirect or no experience tend to underestimate the danger compared to those with direct experience (Ruin et al., 2007).

It is also interesting to note that while many survey respondents were not familiar with the Break the Grip of the Rip! ${ }^{\circledR}$ campaign itself, a clear majority $(\sim 91 \%)$ understood the primary message of the campaign and were able to provide an accurate explanation of the message (i.e., "break the grip"). Respondents previously familiar with the campaign provided detailed explanations of how to escape a rip by swimming parallel and/or floating until the current weakened, indicating they may also have gained this knowledge from other sources.

Survey results also suggest that other factors can influence behavioral response in relation to the rip current hazard. For example, as noted by several survey respondents, if everyone else at the beach is entering the water and not heeding an existing rip current warning (out of ignorance or purposeful neglect), there is a chance that the beach user may become 
Table 2. Summary of major findings from the "Break the Grip of the Rip!" ${ }^{\circledR}$ national rip current survey.

\begin{tabular}{|c|c|}
\hline Focus of questions & Example topics \\
\hline Beach preference & $\begin{array}{l}\text { Frequency and purpose of visits to a beach affect perception of surf conditions, importance of } \\
\text { swimming near a lifeguard, and self-reported ability to spot a rip current }\end{array}$ \\
\hline Swimming ability & $\begin{array}{l}\text { Range of self-reported swimming ability (distance in open water) related to self-reported com- } \\
\text { petency }\end{array}$ \\
\hline Ability to identify a rip current & $\begin{array}{l}\text { Ability to identify safest location in a photograph related to frequency of beach visits, self- } \\
\text { reported swimming competency, and training } \\
\text { Ability to identify safest location related to perceived importance of and concern about surf haz- } \\
\text { ards, self-reported understanding of "high" and "low" risk conditions, and perceived accuracy } \\
\text { of rip forecasts }\end{array}$ \\
\hline Response to warning sign & $\begin{array}{l}\text { Perceived ability to use sign to identify a rip current varied with ability to identify safest location } \\
\text { on a photograph } \\
\text { Sign has been effective in communicating swimming parallel as an escape strategy and taking } \\
\text { caution when entering the water } \\
\text { Identified need to provide a more accurate depiction of a rip current, detailed instructions on } \\
\text { how to escape a rip current, and local emergency information }\end{array}$ \\
\hline Prevention & $\begin{array}{l}\text { Break the Grip of the Rip! }{ }^{\circledR} \text { campaign has been successful in informing beach users to } \\
\text { (1) not fight the current; } \\
\text { (2) swim out of the current, then to shore; } \\
\text { (3) if you can't escape, float or tread water; and } \\
\text { (4) if you need help, call or wave for assistance. }\end{array}$ \\
\hline Forecasts & $\begin{array}{l}\text { Self-reported change in behavior based on forecasted beach and surf conditions, but tendency } \\
\text { for forecasts to be inconsistent with observations } \\
\text { Perceived inaccuracy of forecast related to spatial and temporal broadness of forecast, inability } \\
\text { to identify a rip, and behavior of other beach users }\end{array}$ \\
\hline Trusted sources of information & $\begin{array}{l}\text { No significant correlations were observed between trust in a source of information and respon- } \\
\text { dent demographics }\end{array}$ \\
\hline
\end{tabular}

complacent and also enter the water despite understanding the risk. This suggests that decisions can be made based on what other beach users are doing rather than rip forecasts (Lapinski et al., 2014). The tendency to follow the behavior of others may be enhanced when someone goes together as part of a group and enters the water because everyone is willfully ignoring the risk or is ignorant to the severity of the risk (see Mollen et al., 2012; Arozarena et al., 2015). A regional forecast or global warning will not necessarily deter beach user behavior as much as direct intervention by lifeguards.

This study has also revealed some important issues with existing rip forecasting methods and resultant warnings (Table 2). Approximately $67 \%$ of all respondents stated that rip current forecasts are not necessarily consistent with what they observe on the beach. Consistent with previous studies on natural hazards, those who have not experienced a predicted hazard or did not experience personal damage during a visit to the beach are more likely to downplay the danger the next time they visit (Hall and Slothower, 2009; Scolobig et al., 2012; Green et al., 1991; Mileti and O'Brien, 1993). Any inconsistency between a rip forecast and direct observations therefore has the potential for some beach users to downplay the rip current risk on future beach visits. While forecast methodology varies by WFO, most rip forecasts do not consider bathymetry, local topography, or hard structures that may force rips over a range of wind wave conditions. It is also not clear how many forecasts are based on the actual presence of rips observed by lifeguards.

The key problem is that rip forecasts tend to be generalized for a large region and time, whereas actual rip development and flow behavior is extremely variable over space and time (Castelle et al., 2016a). It is also difficult to predict the potential for rip development without an understanding of the pre-existing nearshore morphology, which itself is difficult to measure directly, remotely, or through numerical modeling. A static daily regional rip warning may therefore fail to replicate different rip conditions that occur during that day. For beachgoers, this can lead to a different interpretation of the forecast accuracy and may potentially lead to downplaying the actual risk (see Brilly and Polic, 2005). Mileti and O'Brien (1993, p. 40) describe this reasoning as "The first impact did not affect me negatively, therefore, subsequent impacts will also avoid me." At the same time, beach users will not be able to conceptualize events that have never oc- 
curred or to see future trips to the beach as anything more than a mirror of past visits or experiences (Kates, 1962; Tversky and Kahneman, 1973). If the rip forecast and warnings are inaccurate or perceived to be inaccurate by the beach user, there may also be a potential loss of trust in that authority (Espluga et al., 2009) and future forecasts.

It can be assumed that beach users who rely heavily on rip forecasts and assume they are accurate might use them to calibrate their own observations and experiences, which will impact their future forecast expectations. If a low rip risk forecast is issued and the rips are prevalent and strong, then beach users may lose faith in forecast accuracy. Similarly, if a high rip risk forecast is issued and no rips are observed with relatively calm conditions, then beach users may become complacent about the hazard and discount or ignore future forecasts in the future. However, results of this study suggest that given time and experience at the beach over a range of conditions, beach users can develop a nuanced understanding of the forecast and gain greater confidence that it is appropriate. Rip forecast inaccuracies appear to be most problematic for infrequent beach users who also do not appear to seek out lifeguards and are unable to spot rips correctly.

Most respondents could clearly state what the standardized rip current sign was informing them to do in terms of swimming parallel to the beach to escape the rip, but many identified a need to provide information that would allow beach users to identify a rip current in general (e.g., "Pictures showing what actual rip currents look like would be useful") or specific to the local beach (e.g., "Picture of rip at actual beach [the sign] is placed on"). However, evidence from beach surveys in Florida and Texas suggest that beach users are not able to accurately identify a rip current (Caldwell et al., 2012; Brannstrom et al., 2014), although there may be ways in which the sign can be made more accurate through small revisions to the perspective, colors, and beach morphology (Brannstrom et al., 2015). While local information may improve the accuracy and interpretation of the sign, there is the potential for different signs and messaging being used (of varying quality and detail), leading to confusion and misinterpretation by beach users. A more appropriate strategy may be to take a more local approach to risk and emergency management including local emergency contact information. This approach places greater authority in local managers and emergency responders, without resulting in different signs.

A local approach also includes putting greater emphasis on the expertise of lifeguards to prevent accidents and respond to emergencies promptly and properly. This would also partially consider the fact that there are different types of rip currents and associated behavior in different geographic locations and regions (Castelle et al., 2016b). Of note, Surf Life Saving Australia has recently adopted a "combined approach" to promoting how to escape a rip current (Bradstreet et al., 2014). This decision was largely based on field tests of rip escape strategies (McCarroll et al., 2014; Van Leeuwen et al., 2016), which clearly showed that natural variance in rip flow behavior influences effectiveness of different rip escape strategy strategies. This has also been illustrated by recent numerical modeling studies (McCarroll et al., 2015; Castelle et al., 2016a, b). However, communicating such a complex and mixed message is problematic. In contrast, concepts of rip avoidance instruction are consistent and simpler to explain, making them more suitable for advertising campaigns and signage (Bradstreet et al., 2014).

While there is still insufficient evidence to suggest that present warning systems help people avoid and escape rip currents (see also Lapinski et al., 2014), there is evidence that lifeguards are effective at preventing drowning death through preventive actions and rescues. With proper training and experience a lifeguard can provide invaluable local understanding of the rip hazard to provide effective mitigation. Unfortunately, there is no consensus amongst beach users that it is safe (or not) to swim in the surf after lifeguards are off duty (Petrass and Blitvich, 2014), despite evidence that it is safer to swim in the presence of a lifeguard. In this respect, greater focus should be placed on reminding beach users to swim near lifeguards and only at times that lifeguards are present because "the chances of drowning at a beach protected by lifeguards trained under USLA standards is less than 1 in 18 million" (Branche et al., 2001).

\section{Conclusions}

A survey about the extent of public rip current knowledge in the United States was conducted with the aim of establishing a dataset that provides guidance for the improvement and enhancement of existing beach safety interventions. Results suggest that the US-based Break the Grip of the Rip! ${ }^{\circledR}$ campaign has been successful in helping inform the public about rip current safety. Although few respondents were familiar with the campaign itself, most respondents could provide an accurate description of how to escape a rip current by swimming parallel and/or floating until the current weakened. Results suggest that the most at-risk population are infrequent beach users because they do not seek out lifeguards, do not take the same precautions as frequent beach users, and believe there are large discrepancies between rip forecasts and their own observations at the beach. Survey results provide a conservative estimate of $10 \%$ of US beachgoers being at risk of being caught in a rip due to ignorance and/or poor swimming choices. Future education efforts should attempt to target this beach-going demographic group. Knowledge of rips, visual ability to accurately identify a safe swimming location in where rip currents are present, and ability to interpret rip forecasts are each dependent on prior experience with rips and the frequency of beach visitation. In addition to concerns about the spatial and temporal accuracy of public rip forecasts, many respondents identified a lack of local detail in 
the rip current warning sign as a concern, with more than half of respondents suggesting the sign needed to provide a more accurate depiction and/or description of a rip current and local emergency information. This suggests a need for greater focus on locally specific and verified rip forecasts and signage in coordination with lifeguards, but not at the expense of the successful Break the Grip of the Rip! ${ }^{\circledR}$ campaign.
Data availability. This study was approved by the relevant human subject protection program from Texas A\&M University (IRB20150330D). While the identity of the participant cannot readily be determined by the investigator and the identity of the participant is not connected to information gathered, the approval requires that the records of this study will be kept private and stored securely for 3 years before being destroyed. 


\section{Appendix A}

Table A1. Survey instrument.

\begin{tabular}{|c|c|}
\hline Question & Response \\
\hline Are you a resident of the United States? & Yes/no \\
\hline $\begin{array}{l}\text { If resident - in what state do you currently re- } \\
\text { side? }\end{array}$ & List of US states \\
\hline If resident - what is your zip code? & Open response \\
\hline If not resident - in which country do you reside? & List of countries \\
\hline Which best describes your gender? & Male/female/no response \\
\hline What is your age? & $\begin{array}{l}\square 18-20 \text { years } \\
\square 21-30 \text { years } \\
\square 31-40 \text { years } \\
\square 41-50 \text { years } \\
\square 51-60 \text { years } \\
\square 61-64 \text { years } \\
\square 65 \text { years and over }\end{array}$ \\
\hline $\begin{array}{l}\text { Which statement about beach visitation best de- } \\
\text { scribes your experience? }\end{array}$ & $\begin{array}{l}\square \text { Infrequently (fewer than } 10 \text { times in my life) } \\
\square \text { Once every year typically on vacation } \\
\square \text { I go multiple times per year } \\
\square \text { Several times per month } \\
\square \text { Frequently (weekly or daily) }\end{array}$ \\
\hline $\begin{array}{l}\text { How would you describe the beaches that you } \\
\text { commonly visit? }\end{array}$ & $\begin{array}{l}\square \text { Calm with small to no waves } \\
\square \text { Occasional wave activity, primarily during storms } \\
\square \text { Regular wave activity but typically small- or medium-sized waves } \\
\square \text { Strong waves are common }\end{array}$ \\
\hline $\begin{array}{l}\text { What is the main type of activity you do when } \\
\text { you go to the beach? }\end{array}$ & $\begin{array}{l}\square \text { Swimming and wading } \\
\square \text { Board riding (including surfboard, boogie board, stand up, etc.) } \\
\square \text { Beach activities only (sunbathing, shell collecting, etc.) } \\
\square \text { Snorkeling or diving } \\
\square \text { Other }\end{array}$ \\
\hline $\begin{array}{l}\text { If other selected - describe what you tend to do } \\
\text { at the beach. }\end{array}$ & Open response \\
\hline $\begin{array}{l}\text { Have you ever had swimming lessons or train- } \\
\text { ing, either in a pool or ocean? }\end{array}$ & Yes/no \\
\hline $\begin{array}{l}\text { How would you rate your pool swimming abil- } \\
\text { ity? }\end{array}$ & $\begin{array}{l}\square \text { Unable to swim } \\
\square \text { Weak swimmer } \\
\square \text { Competent swimmer } \\
\square \text { Highly competent swimmer }\end{array}$ \\
\hline $\begin{array}{l}\text { How far do you think you can swim in a pool } \\
\text { before you have to stop/pause? }\end{array}$ & $\begin{array}{l}\square \text { I can't swim } \\
\square \text { Less than } 25 \text { yards (one length of a typical community swimming pool) } \\
\square \text { More that } 25 \text { yards but less than } 100 \text { yards } \\
\square \text { More than } 100 \text { yards but less than } 500 \text { yards } \\
\square \text { More than } 500 \text { yards }\end{array}$ \\
\hline $\begin{array}{l}\text { How would you rate your swimming ability in } \\
\text { open water with waves (like an ocean or lake)? }\end{array}$ & $\begin{array}{l}\square \text { I have never swum in water with lots of waves } \\
\square \text { Weak swimmer } \\
\square \text { Competent swimmer } \\
\square \text { Highly competent swimmer }\end{array}$ \\
\hline
\end{tabular}


Table A1. Continued.

\begin{tabular}{|c|c|}
\hline Question & Response \\
\hline $\begin{array}{l}\text { How far do you think you can swim in open wa- } \\
\text { ter with waves before you have to stop/pause? }\end{array}$ & $\begin{array}{l}\square \text { Less than } 25 \text { yards } \\
\square \text { More than } 25 \text { yards but less than } 100 \text { yards } \\
\square \text { More than } 100 \text { yards but less than } 500 \text { yards } \\
\square \text { More than } 500 \text { yards } \\
\square \text { I can't swim }\end{array}$ \\
\hline $\begin{array}{l}\text { Have you ever swum in an open ocean or lake } \\
\text { with lots of wave breaking? }\end{array}$ & $\begin{array}{l}\square \text { Yes } \\
\square \text { No } \\
\square \text { Unsure }\end{array}$ \\
\hline $\begin{array}{l}\text { What is the most important factor for you when } \\
\text { choosing an ocean or lake beach to visit, with } \\
\text { the intention of going into the water? }\end{array}$ & $\begin{array}{l}\square \text { Safety (e.g., are not prone to theft) } \\
\square \text { Safety in the water (avoid dangerous water hazards) } \\
\square \text { Lifeguard presence } \\
\square \text { Cleanliness of the beach and water } \\
\square \text { Crowds (prefer to be on a popular beach) } \\
\square \text { Crowds (prefer to be on a secluded, private or empty beach) } \\
\square \text { Ease of access } \\
\square \text { Avoid lots of breaking waves (i.e., prefer calm conditions) } \\
\square \text { Prefer lots of breaking waves } \\
\square \text { Other }\end{array}$ \\
\hline $\begin{array}{l}\text { You answered "other" to the previous questions. } \\
\text { Please describe the most important factor for } \\
\text { you when choosing an ocean or lake beach to } \\
\text { visit. }\end{array}$ & Open response \\
\hline $\begin{array}{l}\text { When you go to the beach, how important is it } \\
\text { to you to swim near a lifeguard? }\end{array}$ & $\begin{array}{l}\square \text { Not important } \\
\square \text { Important } \\
\square \text { Very important }\end{array}$ \\
\hline $\begin{array}{l}\text { If you visit a beach with no lifeguards, do you } \\
\text { still go into the water to wade, swim, or float? }\end{array}$ & $\begin{array}{l}\square \text { Always } \\
\square \text { Most of the time } \\
\square \text { Sometimes } \\
\square \text { Rarely } \\
\square \text { Never }\end{array}$ \\
\hline $\begin{array}{l}\text { Do you think about or check for hazards when } \\
\text { you go to the beach? }\end{array}$ & $\begin{array}{l}\square \text { Always } \\
\square \text { Most of the time } \\
\square \text { Sometimes } \\
\square \text { Rarely } \\
\square \text { Never }\end{array}$ \\
\hline $\begin{array}{l}\text { What do you think is the most dangerous hazard } \\
\text { when you swim, wade, or float at the beach? }\end{array}$ & $\begin{array}{l}\square \text { Jellyfish } \\
\square \text { Sharks } \\
\square \text { Big waves } \\
\square \text { Shore breaks } \\
\square \text { Undertow } \\
\square \text { Alongshore currents } \\
\square \text { Rip currents } \\
\square \text { Surfboards/boogie boards/other swimmers } \\
\square \text { Sunburn } \\
\square \text { Other }\end{array}$ \\
\hline
\end{tabular}

You answered "other" to the previous question.

Please identify what you think is the most dan-

Open response gerous hazard at the beach. 
Table A1. Continued.

\begin{tabular}{ll}
\hline Question & Response \\
\hline Have you ever seen or heard information about & $\square$ Never \\
beach hazards. Please select all that apply. & $\square$ Yes, in primary school \\
& $\square$ Yes, in high school \\
& $\square$ Yes, at university/college \\
& $\square$ Yes, from my parents \\
& $\square$ Yes, through pamphlets and brochures \\
& $\square$ Yes, through warning signs on the beach \\
& $\square$ Yes, on the Internet \\
& $\square$ Yes, on television \\
& $\square$ Yes, on the radio \\
& $\square$ Yes, at my rental property in the guide material \\
& $\square$ Other
\end{tabular}

You answered "other" to the previous question.

Please describe where you have heard about

Open response

beach hazards.

Are you familiar with any beach safety flag sys- $\quad$ Yes/no

tem in the United States?

You answered "yes" to the previous question.

Can you describe what you know about the

Open response

beach safety flag system in the United States?

\begin{tabular}{|c|c|}
\hline Have you heard of rip currents? & $\begin{array}{l}\square \text { Yes } \\
\square \text { No }\end{array}$ \\
\hline Can you describe a rip current? & Open response \\
\hline $\begin{array}{l}\text { Where have you learned/heard about rip cur- } \\
\text { rents? Select all that apply. }\end{array}$ & $\begin{array}{l}\square \text { I have never heard of a rip current } \\
\square \text { Television } \\
\square \text { Magazine/book } \\
\square \text { Radio } \\
\square \text { Primary school } \\
\square \text { High school } \\
\square \text { College/university } \\
\square \text { Parents } \\
\square \text { Pamphlets and/or brochures } \\
\square \text { Internet } \\
\square \text { Beach signs } \\
\square \text { Lifeguard } \\
\square \text { I have been caught in one (direct experience) } \\
\square \text { Other }\end{array}$ \\
\hline $\begin{array}{l}\text { You answered "other" to the previous question. } \\
\text { Please tell us where you have heard about rip } \\
\text { currents. }\end{array}$ & Open response \\
\hline $\begin{array}{l}\text { If you were at a beach, would you know how to } \\
\text { spot a rip current? }\end{array}$ & $\begin{array}{l}\square \text { Yes, always } \\
\square \text { Yes, sometimes } \\
\square \text { No } \\
\square \text { You can't see a rip current } \\
\square \text { Unsure }\end{array}$ \\
\hline
\end{tabular}

You answered "yes" to the previous question.

Can you describe what a rip current looks like?

Open response 
Table A1. Continued.

Question
Where on this photograph would you feel most
safe to enter the water? Click on the picture at
the spot along the beach that you believe is the
safest.
Where on this photograph would you feel most
safe to enter the water? Click on the picture at
the spot along the beach that you believe is the
safest.
Where on this photograph would you feel most
safe to enter the water? Click on the picture at
the spot along the beach that you believe is the
safest.

Explain what you should do if caught in a rip Open response current?

\begin{tabular}{ll}
\hline Have you ever been caught in a rip current? & $\square$ Yes, I was caught in a rip by accident \\
& $\square$ Yes, I used the rip on purpose (e.g., for surfing) \\
& $\square$ No \\
& $\square$ Not sure \\
\hline You answered that you had been caught in a & Open response \\
rip current. Where (ie. what beach) were you & \\
caught in a rip current? & \\
\hline You answered that you were caught in a rip cur- & $\square$ Self-escaped by swimming parallel to the beach first, then back to the beach \\
rent by accident. How did you get out of the rip & $\square$ Self-escaped by swimming straight back to the beach \\
current the first time this happened to you? & $\square$ Self-escaped by just floating \\
& $\square$ Rescued by lifeguard \\
& $\square$ Rescued by bystander (e.g., family, friend, stranger, surfer) \\
& $\square$ Don't know/can't remember \\
\hline Before going to the beach, do you get informa- & $\square$ Yes \\
tion on the beach and surf conditions for the & $\square$ No \\
day? & \\
\hline You answered "yes" to the previous question. & $\square$ Radio \\
What source do you use to get information on & $\square$ Television \\
the beach and surf conditions for the day? Select & $\square$ Internet \\
all that apply. & $\square$ Facebook or other social media \\
& $\square$ Acquaintance \\
& $\square$ Other \\
\hline
\end{tabular}

You answered "other" to the previous question. Please explain the other source of information Open response about beach and surf conditions that you use. 
Table A1. Continued.

\begin{tabular}{|c|c|}
\hline Question & Response \\
\hline $\begin{array}{l}\text { Does this information tend to affect your behav- } \\
\text { ior when you go to the beach? }\end{array}$ & $\begin{array}{l}\square \text { It doesn't affect my behavior } \\
\square \text { It affects my behavior }\end{array}$ \\
\hline $\begin{array}{l}\text { Please explain how it affects your behavior at } \\
\text { the beach. }\end{array}$ & Open response \\
\hline $\begin{array}{l}\text { Rank the following sources of information from } \\
\text { "most trusted" (1) to "least trusted" (5). }\end{array}$ & $\begin{array}{l}\text { Radio } \\
\text { Television } \\
\text { Internet } \\
\text { Facebook or other social media } \\
\text { Acquaintance }\end{array}$ \\
\hline $\begin{array}{l}\text { Please explain why you trust one source of in- } \\
\text { formation more than another. }\end{array}$ & Open response \\
\hline $\begin{array}{l}\text { Have you ever seen beach safety information at } \\
\text { the entrance to, or on beaches, that you have vis- } \\
\text { ited? }\end{array}$ & $\begin{array}{l}\square \text { Yes } \\
\square \text { No }\end{array}$ \\
\hline $\begin{array}{l}\text { What type of beach safety information do you } \\
\text { remember seeing? }\end{array}$ & $\begin{array}{l}\square \text { Signs/posters } \\
\square \text { Flags } \\
\square \text { Pamphlets/brochures } \\
\square \text { Other }\end{array}$ \\
\hline $\begin{array}{l}\text { You answered "other" to the previous question. } \\
\text { Please explain the type of beach safety infor- } \\
\text { mation that you tend to see at the entrance to } \\
\text { the beach. }\end{array}$ & Open response \\
\hline $\begin{array}{l}\text { Where do you tend to see the beach safety in- } \\
\text { formation? }\end{array}$ & $\begin{array}{l}\square \text { At the entrance to the beach } \\
\square \text { On the beach } \\
\square \text { Both on the beach and at the entrance to the beach }\end{array}$ \\
\hline $\begin{array}{l}\text { What is the primary message of the safety in- } \\
\text { formation that you tend to see? }\end{array}$ & Open response \\
\hline $\begin{array}{l}\text { Have you ever heard of the national United } \\
\text { States rip current education campaign called } \\
\text { Break the Grip of the Rip! }{ }^{\circledR} \text { ? }\end{array}$ & $\begin{array}{l}\square \text { Yes } \\
\square \text { No }\end{array}$ \\
\hline $\begin{array}{l}\text { You answered "yes" to the previous question. } \\
\text { Please tell us where you heard or have seen in- } \\
\text { formation related to the Break the Grip of the } \\
\text { Rip! }{ }^{\circledR} \text { campaign. Select all that apply }\end{array}$ & $\begin{array}{l}\square \text { Radio } \\
\square \text { Television } \\
\square \text { Newspaper } \\
\square \text { Magazine/book } \\
\square \text { Local magazine or newspaper during my stay } \\
\square \text { Brochure/pamphlet } \\
\square \text { At my rental property here } \\
\square \text { Primary school } \\
\square \text { High school } \\
\square \text { College/university } \\
\square \text { Parents } \\
\square \text { Internet } \\
\square \text { Break the Grip of the Rip! }{ }^{\circledR} \text { website } \\
\square \text { YouTube or other Internet video site } \\
\square \text { Facebook } \\
\square \text { Twitter } \\
\square \text { Other social media } \\
\square \text { Signs at the entrance to a beach } \\
\square \text { Signs on the beach } \\
\square \text { Lifeguards } \\
\square \text { Other }\end{array}$ \\
\hline
\end{tabular}


Table A1. Continued.

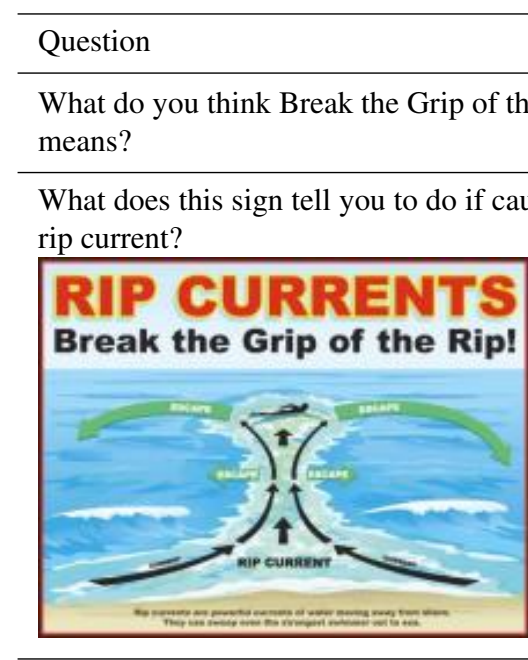

\begin{tabular}{|c|c|}
\hline $\begin{array}{l}\text { If you see this sign at a beach, how would it } \\
\text { change your behavior at the beach? }\end{array}$ & $\begin{array}{l}\square \text { Yes } \\
\square \text { No }\end{array}$ \\
\hline Does this sign help you identify a rip current? & Open response \\
\hline $\begin{array}{l}\text { You answered "yes" to the previous question. } \\
\text { How does it help you identify a rip current? }\end{array}$ & Open response \\
\hline $\begin{array}{l}\text { What other information would be useful to be } \\
\text { included in the Break the Grip of the Rip! }{ }^{\circledR} \\
\text { sign? }\end{array}$ & Open response \\
\hline $\begin{array}{l}\text { Have you ever seen or heard rip current fore- } \\
\text { casts from the following sources? Select all that } \\
\text { apply. }\end{array}$ & $\begin{array}{l}\square \text { Radio } \\
\square \text { Newspaper } \\
\square \text { Television } \\
\square \text { Internet } \\
\square \text { Social media } \\
\square \text { No }\end{array}$ \\
\hline
\end{tabular}

Do you understand what it means if there is a $\square$ Yes

"high risk" for rip currents? $\square$ No

You answered "yes" to the previous question. Open response

What does a high risk of rip currents mean?

Do you understand what it means if there is a $\square$ Yes

"low risk" for rip currents? $\square$ No

You answered "yes" to the previous question. Open response

What does a low risk of rip currents mean?

Do you adjust your activities at the beach based Open response

on the rip forecast?

If you heard a rip current forecast (e.g., low risk $\square$ Yes

or high risk) and went to the beach on the same $\quad \square$ No

day, did the forecast match the conditions that you encountered at the beach?

You answered "no" to the previous question.

How did the conditions that you encountered

Open response

differ from the conditions that you experienced at the beach? 
Competing interests. The authors declare that they have no conflict of interest.

Edited by: Vassiliki Kotroni

Reviewed by: Robin Davidson-Arnott and Olga Petrucci

\section{References}

Arozarena, I., Houser, C., Echeverria, A. G., and Brannstrom, C.: The rip current hazard in Costa Rica, Nat. Hazards, 77, 753-768, 2015.

Arun Kumar, S. V. V. and Prasad, K. V. S. R.: Rip current-related fatalities in India: a new predictive risk scale for forecasting rip currents, Nat. Hazards, 70, 313-335, 2014.

Ashley, W. S. and Black, A. W.: Fatalities associated with nonconvective high-wind events in the United States, J. Appl. Meteorol. Climatol., 47, 717-725, 2008.

Barnes, P. H.: Approaches to community safety: risk perception and social meaning, Aust. J. Emerg. Manag., 1, 15-23, 2002.

Barrett, G. and Houser, C.: Identifying hotspots of rip current activity using wavelet analysis at Pensacola Beach, Florida, Phys. Geogr., 33, 32-49, 2012.

Bradstreet, A. J., Brander, R. W., McCarroll, J. R., Brighton, B., Dominey Howes, D., Drozdzewski, D., Sherker, S., Turner, I., Roberts, A., and MacMahan, J.: Rip current survival principles: Towards consistency, J. Coastal Res., 72, 85-92, https://doi.org/10.2112/SI72-016.1, 2014.

Branche, M.: Lifeguard effectiveness: A report of the working group, Atlanta, GA, Centers for Disease Control and Prevention, National Center for Injury Prevention and Control, 2001.

Brander, R. W., Bradstreet, A., Sherker, S., and MacMahan, J.: Responses of swimmers caught in rip currents: perspectives on mitigating the global rip current hazard, Int. J. Aquat. Res. Educ., 5, 476-482, 2011.

Brander, R., Dominey-Howes, D., Champion, C., Del Vecchio, O., and Brighton, B.: Brief Communication: A new perspective on the Australian rip current hazard, Nat. Hazards Earth Syst. Sci., 13, 1687-1690, https://doi.org/10.5194/nhess-131687-2013, 2013.

Brannstrom, C. and Houser, C.: "Riding the rip": an experiential and integrated human-physical geography curriculum in Costa Rica, J. Geogr. Higher Educ., 39, 527-542, 2015.

Brannstrom, C., Trimble, S., Santos, A., Brown, H. L., and Houser, C.: Perception of the rip current hazard on Galveston Island and North Padre Island, Texas, USA, Nat. Hazards, 72, 1123-1138, 2014.

Brannstrom, C., Brown, H. L., Houser, C., Trimble, S., and Santos, A.: "You can't see them from sitting here": Evaluating beach user understanding of a rip current warning sign, Appl. Geogr., 56, 61-70, 2015.

Brighton, B., Sherker, S., Brander, R., Thompson, M., and Bradstreet, A.: Rip current related drowning deaths and rescues in Australia 2004-2011, Nat. Hazards Earth Syst. Sci., 13, 10691075, https://doi.org/10.5194/nhess-13-1069-2013, 2013.

Brilly, M. and Polic, M.: Public perception of flood risks, flood forecasting and mitigation, Nat. Hazards Earth Syst. Sci., 5, 345-355, https://doi.org/10.5194/nhess-5-345-2005, 2005.
Caldwell, N., Houser, C., and Meyer-Arendt, K.: Ability of beach users to identify rip currents at Pensacola Beach, Florida, Nat. Hazards, 68, 1041-1056, 2013.

Carey, W. and Rogers, S.: Rip currents: coordinating coastal research, outreach and forecast methodologies to improve public safety, in: Solutions to Coastal Disasters 2005, ASCE, 285-296, 2005.

Castelle, B., McCarroll, R. J., Brander, R. W., Scott, T., and Dubarbier, B.: Modelling the alongshore variability of optimum rip current escape strategies on a multiple rip-channelled beach, Nat. Hazards, 81, 664-686, 2016 a.

Castelle, B., Scott, T., Brander, R. W., and McCarroll, R. J.: Rip current types, circulation and hazard, Earth-Sci. Rev., 163, 1-21, $2016 b$.

Drozdzewski, D., Shaw, W., Dominey-Howes, D., Brander, R., Walton, T., Gero, A., Sherker, S., Goff, J., and Edwick, B.: Surveying rip current survivors: preliminary insights into the experiences of being caught in rip currents, Nat. Hazards Earth Syst. Sci., 12, 1201-1211, https://doi.org/10.5194/nhess-12-1201-2012, 2012.

Drozdzewski, D., Roberts, A., Dominey-Howes, D., and Brander, R.: The experiences of weak and non-swimmers caught in rip currents at Australian beaches, Aust. Geogr., 46, 15-32, 2015.

Espluga, J., Gamero, N., Prades, A., and Solà, R.: El papel de la confianza en los conflictos socio ambientales, Política y sociedad 46, 225-273, 2009.

Gensini, V. A. and Ashley, W. S.: An examination of rip current fatalities in the United States, Nat. Hazards, 54, 159-175, 2010.

Green, C. H., Tunstall, S. M., and Fordham, M. H.: The risks from flooding: Which risks and whose perception?, Disasters, 15, 227-236, 1991.

Hall, T. E. and Slothower, M.: Cognitive factors affecting homeowners' reactions to defensible space in the Oregon coast range, Soc. Natur. Resour., 22, 95-110, 2009.

Hartmann, D.: Drowning and Beach-Safety Management (BSM) along the Mediterranean Beaches of Israel - a long-term perspective, J. Coastal Res., 22, 1505-1514, 2006.

Hatfield, J., Williamson, A., Sherker, S., Brander, R., and Hayen, A.: Development and evaluation of an intervention to reduce rip current related beach drowning, Accident Anal. Prev., 46, 45-51, 2012.

Heitz, C., Spaeter, S., Auzet, A. V., and Glatron, S.: Local stakeholders' perception of muddy flood risk and implications for management approaches: A case study in Alsace (France), Land Use Policy, 26, 443-451, 2009.

Houser, C., Caldwell, N., and Meyer-Arendt, K.: Rip Current Hazards at Pensacola Beach, Florida, Rip currents: beach safety, physical oceanography, and wave modeling, p. 175, $2011 \mathrm{a}$.

Houser, C., Barrett, G., and Labude, D.: Alongshore variation in the rip current hazard at Pensacola Beach, Florida, Nat. Hazards, 57, 501-523, 2011b.

Houser, C., Arnott, R., Ulzhöfer, S., and Barrett, G.: Nearshore Circulation over Transverse Bar and Rip Morphology with Oblique Wave Forcing, Earth Surf. Proc. Land., 38, 1269-1279, 2013.

Houser, C., Murphy, T., and Labude, D.: Alongshore correspondence of beach users and rip channels at Pensacola Beach, Florida, Nat. Hazards, 78, 2175-2183, 2015.

Houser, C., Brander, R., Brannstrom, C., Trimble, S., and Flaherty, J.: Case Study of Rip Current Knowledge amongst Students 
Participating in a Study Abroad Program, Frontiers, 28, 42-60, 2016.

Jóhannesdóttir, G. and Gísladóttir, G.: People living under threat of volcanic hazard in southern Iceland: vulnerability and risk perception, Nat. Hazards Earth Syst. Sci., 10, 407-420, https://doi.org/10.5194/nhess-10-407-2010, 2010.

Karanci, A. N., Aksit, B., and Dirik, G.: Impact of a community disaster awareness training program in Turkey: Does it influence hazard-related cognitions and preparedness behaviors, Soc. Behav. Personal., 33, 243-258, 2005.

Kates, R. W.: Hazard and choice perception in flood plain management. Chicago, Illinois, University of Chicago, 157 pp., 1962.

Klein, A. H., Santana, G. G., Diehl, F. L., and Menezes, J. T.: Analysis of hazards associated with sea bathing: results of five years work in oceanic beaches of Santa Catarina State, Southern Brazil, J. Coastal Res., 35, 107-116, 2003.

Lapinski, M. and Viken, G.: Great Lakes Swim Safety Risk Communication for 18-24 year-old Males: Review of Key Literature and Results of a Focus Group Study Final Report, 2014.

Lushine, J. B.: A study of rip current drownings and related weather factors, Natl. Weather Digest, 1991.

Matthews, B., Andronaco, R., and Adams, A.: Warning signs at beaches: Do they work?, Safety Sci., 62, 312-318, 2014.

McCarroll, R. J., Brander, R. W, MacMahan, J. H., Turner, I. L., Reniers, A. J. H. M, Brown, J., Bradstreet, A., and Sherker, S.: Evaluation of swimmer-based rip current escape strategies, Nat. Hazards, 71, 1821-1846, 2014.

McCarroll, R. J., Castelle, B., Brander, R. W., and Scott, T.: Modelling rip current flow and bather escape strategies across a transverse bar and rip channel morphology, Geomorphology, 246, 502-518, 2015.

Mileti, D. S. and O'Brien, P.: Public response to aftershock warnings, US geological survey professional paper, 1553, 31-42, 1993.

Morgan, D., Ozanne-Smith, J., and Triggs, T.: Self-reported water and drowning risk exposure at surf beaches, Aust. Nz. J. Publ. Heal., 33, 180-188, 2009.

Njome, M. S., Suh, C. E., Chuyong, G., and de Wit, M. J.: Volcanic risk perception in rural communities along the slopes of mount Cameroon, West-Central Africa, J. Afr. Earth Sci., 58, 608-622, 2010.

NOAA: The NOAA coastal hazards resilience workshop: Rip currents and wave runup, Virginia Modeling, Analysis, and Simulation Center, Suffolk, Virginia, 14-16 April, 2015.

Petrass, L. A. and Blitvich, J. D.: Preventing adolescent drowning: Understanding water safety knowledge, attitudes and swimming ability. The effect of a short water safety intervention, Accident. Anal. Prev., 70, 188-194, 2014.
Ruin, I., Gaillard, J. C., and Lutoff, C.: How to get there? Assessing motorists' flash flood risk perception on daily itineraries, Environ. Hazards, 7, 235-244, 2007.

Sabet, B. S. and Barani, Gh. A.: Field investigation of rip currents along the southern coast of the Caspian Sea, Sci. Iran. Trans. A, 18, 878-884, 2011.

Scolobig, A., De Marchi, B., and Borga, M.: The missing link between flood risk awareness and preparedness: findings from case studies in an Alpine Region, Nat. Hazards, 63, 499-520, 2012.

Sherker, S., Brander, R., Finch, C., and Hatfield, J.: Why Australia needs an effective national campaign to reduce coastal drowning, J. Sci. Med. Sport, 11, 81-83, 2008.

Sherker, S., Williamson, A., Hatfield, J., Brander, R., and Hayen, A.: Beachgoers' beliefs and behaviours in relation to beach flags and rip currents, Accident Anal. Prev., 42, 1785-1804, 2010.

Short, A. D. and Hogan, C. L.: Rip currents and beach hazards: their impact on public safety and implications for coastal management, J. Coastal Res., 12, 197-209, 1994.

Siegrist, M. and Gutscher, H.: Flooding risks: A comparison of lay people's perceptions and expert's assessments in Switzerland, Risk Anal., 26, 971-979, 2006.

Siegrist, M. and Cvetkovich, G.: Perception of hazards: The role of social trust and knowledge, Risk Anal., 20, 713-720, 2000.

Terpstra, T., Lindell, M. K., and Gutteling, J. M.: Does Communicating (Flood) Risk Affect (Flood) Risk Perceptions? Results of a Quasi-Experimental Study, Risk Anal., 29, 1141-1155, 2009.

Terpstra, T.: Emotions, trust, and perceived risk: Affective and cognitive routes to flood preparedness behavior, Risk Anal., 31, 1658-1675, 2011.

Tversky, A. and Kahneman, D.: Availability: A heuristic for judging frequency and probability, Cognitive Psychol., 5, 207-232, 1973.

Van Leeuwen, McCarroll, J. R., Brander, R. W., Turner, I. L., Power, H., and Bradstreet, A.: Examining rip current escape strategies in non-traditional beach morphologies, Nat. Hazards, 81, 145-165, 2016.

Williamson, A., Hatfield, J., Sherker, S., Brander, R., and Hayen, A.: A comparison of attitudes and knowledge of beach safety in Australia for beachgoers, rural residents and international tourists, Aust. Nz. J. Publ. Heal., 36, 385-391, 2012.

Woodward, E., Beaumont, E., Russell, P., Wooler, A., and Macleod, R.: Analysis of rip current incidents and victim demographics in the UK, J. Coastal Res., 65, 850-855, 2013. 